\title{
The yeast nucleoporin Riplp contributes to multiple export pathways with no essential role for its FG-repeat region
}

\author{
Françoise Stutz, ${ }^{1}$ Julia Kantor, Dong Zhang Terri McCarthy, Megan Neville, and Michael Rosbash ${ }^{2}$ \\ Howard Hughes M edical Institute and Department of Biology, Brandeis University, Waltham, M assachusetts 02254 USA
}

\begin{abstract}
The FG-repeat domain of the yeast Ripl protein (Riplp) was identified initially as a possible target for the nuclear export signal (NES) of the HIV-1 Rev protein in a yeast two-hybrid assay. Riplp is inessential, associated with nuclear pore complexes, and structurally related to the FG-nucleoporin family of pore proteins. It contributes to HIV-1 Rev-mediated RNA export and is also important for the export of heat shock RNAs at $42^{\circ} \mathrm{C}$. We show here that Riplp is essential for the export of heat shock RNAs, and this function is fulfilled by the unique carboxyl terminus of Riplp with no substantial contribution from the FG-repeat region. Genetic interactions between Riplp and the RNA export mediator Glelp are described, which support a role of the carboxyl terminus of Riplp in poly(A) ${ }^{+}$RNA export. Finally, this domain of Riplp also contributes to Rev-mediated RNA export. The data suggest that Riplp promotes the nuclear export of different classes of substrates by contributing to optimal pore function.
\end{abstract}

[Key Words: Y east; RN A export; Rev; Riplp; nuclear pore complex; heat shock RN A]

Received June 26, 1997; revised version accepted August 29, 1997.

Macromolecular exchange between the nucleus and the cytoplasm occurs through nuclear pore complexes (N PCs) (Davis 1995; Pante and Aebi 1995). Whereas molecular details of protein import into the nucleus have begun to be elucidated, less is known about the mechanisms of nuclear export of RN A as well as proteins (M elchior and Gerace 1995; Gorlich and Mattaj 1996; Pante and Aebi 1996; Corbett and Silver 1997). Early oocyte injection competition experiments indicated that the transport of each RNA class (i.e., mRNA, U snRNA, $5 S$ RNA, or tRNA) is dependent on one or more specific factors, thus defining distinct RN A export pathways (Jarmolowski et al. 1994). It is also known that RNAs are exported as ribonucleoprotein (RN P) compl exes (Visa et al. 1996a,b) in a process that is saturable and energy dependent. The RN P proteins or the RN As themselves are therefore likely to contain different signals that direct the complexes to and through the nuclear pore in distinct ways (Corbett and Silver 1997; Nigg 1997).

There is evidence that several RNA-binding proteins play a role in RNA export. The mammalian hnRNPA 1 (Michael et al . 1996; Izaurral de et al. 1997) and the yeast hnRN P-like N PL3 (Lee et al. 1996) proteins are involved in mRNA export, the cap-binding complex (CBC) is important for U snRN A export (Izaurral de et al. 1995), and

\footnotetext{
${ }^{1}$ Present address: Microbiology Institute, Centre Hospitalier Universitaire Vaudois, 1011 Lausanne, Switzerland.

${ }^{2}$ Corresponding author.

E-MAIL Rosbash@binah.cc.brandeis.edu; FAX (617) 736-3164.
}

both TFIIIA and the ribosomal L5 protein contribute to 5S RN A export (Guddat et al. 1990). However, no clear connection has yet been established between these RNAbinding proteins and the export machinery or the N PC.

The best characterized protein directly involved in RNA export is the HIV-1 Rev protein. The role of Rev in the viral life cycle is to promote the export of unspliced or partially spliced viral transcripts, which allows the expression of the structural proteins Gag, Pol, and Env, as well as the packaging of the RN A genome into new viral particles (Sodroski et al. 1986). Rev's amino-terminal basic region binds the Rev response el ement (RRE), a highly structured RNA sequence within the target viral transcripts; Rev's carboxyl terminus contains a short leucine-rich motif, the effector domain, directly involved in export (Cullen and Malim 1991). This leucinerich region has been defined as a nuclear export signal (NES), based on the rapid nuclear export of heterol ogous proteins fused to that sequence (Fischer et al. 1995; Gerace 1995). The NES peptide also inhibits U snRNA and 5S RN A export in Xenopus oocytes but has no effect on mRNA or tRNA export, suggesting that Rev uses a specific export pathway (Fischer et al. 1995). Rev-like N ESs have been identified in a number of proteins some of which have no known relevance to RN A export (Wen et al. 1995; Bogerd et al. 1996; Fridell et al. 1996; Fritz and Green 1996; Murphy and Wente 1996; Iovine and Wente 1997; Segref et al. 1997). This suggests that Rev exploits a more general cellular protein export pathway for the transport of viral RNAs. This pathway has been 
evolutionarily conserved, as Rev and Rev-like NES sequences are functional in the yeast Saccharomyces cerevisiae (Stutz and Rosbash 1994; Fritz and Green 1996).

The human hRIP/RAB1 (Bogerd et al. 1995; Fritz et al. 1995) and yeast Riplp (Stutz et al. 1995) proteins interact with the Rev N ES in the yeast two-hybrid assay and have been identified as potential mediators of Rev-mediated RNA export in mammals and yeast, respectively. Both proteins contain a series of phenylal anine-glycine dipeptide repeats (FG repeats), which are important for the two-hybrid interaction with Rev N ES (Stutz et al. 1996). FG repeats are a characteristic feature of a family of N PC proteins, the FG nucleoporins, implicated in the process of nucleocytoplasmic transport (Rout and Wente 1994; Davis 1995; Doye and Hurt 1995; Corbett and Silver 1997). Whereas yeast Riplp (yRiplp) is associated with the N PC (Stutz et al. 1995; see below), hRip1/RAB1 has been detected in the nucleoplasm as well as at the nuclear envel ope (Bogerd et al. 1995; Fritz et al. 1995).

In addition to hRipl/RAB1 and Riplp, Rev NES interacts with the FG repeats of multiple mammalian and yeast FG nucleoporins in the two-hybrid assay (Stutz et al. 1995, 1996; Fritz and Green 1996). Although it is unclear at present which and how many of these interactions are relevant to Rev function in vivo, it is possible that other FG nucleoporins, in addition to hRIP1/RAB1 and Riplp, contribute to Rev-mediated export. In this context, it is interesting that injection into Xenopus oocyte nuclei of a GST-Riplp fusion protein, like injection of a Rev NES peptide, interferes with $U$ snRN A but not mRN A or tRN A export, consistent with a role for Riplp or Riplp-related FG repeats in Rev-mediated export (Stutz et al. 1996).

The ability of Rev NES or other NESs to function in yeast and the identification of Riplp as a cellular target implied the existence of endogenous yeast export factors with comparable properties. A possible candidate is the recently identified Glel protein from yeast. Glelp contains an essential Rev-like NES, and mutations therein result in the nuclear retention of $\operatorname{pol} y(A)^{+}$RN $A$, suggesting that Glelp participates in mRNA export (Murphy and Wente 1996). However, a role for Glelp in the export of other classes of RN As cannot be excluded. Glelp localizes to the N PC as well as the cytoplasm (Del Priore et al. 1996; Murphy and Wente 1996), consistent with the possibility that this protein shuttles between the two compartments. Riplp and Glelp interact in the yeast two-hybrid system as well as in an in vitro blot overlay assay (M urphy and Wente 1996). This further supports a role for Riplp in mRN A export. We note, however, that there is no evidence to date for an interaction between Glelp and Riplp during this process. Moreover, because the disruption of RIPI induces no obvious growth phenotype between $18^{\circ} \mathrm{C}$ and $37^{\circ} \mathrm{C}$ (Stutz et al. 1995), this contribution is inessential and therefore likely to be modest under normal laboratory culture conditions.

Cole and colleagues have recently uncovered an important role for Riplp in the selective export of heat shock RNAs. In a wild-type strain at $42^{\circ} \mathrm{C}$, heat shock RN As are distributed in both the nucl eus and cytopl asm, whereas bulk poly $(A)^{+}$RNA is retained within the nucleus (Saavedra et al . 1996). In a RIP1-deleted strain at $42^{\circ} \mathrm{C}$, however, heat shock RNAs are also prominent within the nucleus and little heat shock RNA-specific signal is detectable in the cytoplasm (Saavedra et al. 1997). These experiments suggest that Riplp is a major component of a pathway dedicated to heat shock RN A export.

In this paper, we pursue these observations by investigating heat shock protein synthesis. Our results confirm the in situ hybridization observations and, surprisingly, reveal no substantial requirement for the Riplp FG repeats but rather point to the uni que carboxy-terminal region of Riplp as being essential for the heat shock RNA export process. We identified several Glel alleles in a screen for mutations that are synthetically lethal in combination with a RIP1 gene disruption, suggesting that Riplp also contributes to the mRNA export pathway. Genetic analyses indicate that this function, like heat shock RNA export, relies predominantly on the unique carboxyl terminus of Riplp. Finally, we show that this region al so contributes to Rev-mediated export. In summary, the data suggest that Riplp participates in multiple export pathways by providing optimal pore structure and/or function through its unique carboxyl terminus.

\section{Results}

The absence of Riplp eliminates heat shock protein synthesis at $42^{\circ} \mathrm{C}$

The in situ hybridization experiments of Saavedra et al . (1997) indicate that Riplp is important for heat shock RNA export. An expected consequence of this selective block is a reduction in heat shock protein synthesis at $42^{\circ} \mathrm{C}$ in a RIP1 deletion strain ( $\triangle \mathrm{RIP1)}$. To verify this prediction, a wild-type and $a_{=} \Delta R I P 1$ strain were incubated at $25^{\circ} \mathrm{C}, 37^{\circ} \mathrm{C}$, or $42^{\circ} \mathrm{C}$ for $15 \mathrm{~min}$ followed by a 15-min labeling pulse with $\left[{ }^{35} \mathrm{~S}\right]$ methionine at the same temperature. Total cell extracts were then fractionated on SDS-PAGE and autoradiographed.

A number of normal cellular protein bands were de tected at $25^{\circ} \mathrm{C}$, which are identical in both wild-type and $\triangle$ RIP1 (Fig. 1A, lanes 1,2 ). In the $42^{\circ} \mathrm{C}$ shifted samples, however, several heat shock proteins (Lindquist 1986; Lindquist and Craig 1988), including Hsp104p, Hsp82p, and SSA 4 (a member of the Hsp70 family of proteins), were strongly induced in the wild-type strain but remained completely absent in the $\Delta$ RIP1 strain (lanes 3,4). This result provides a biochemical confirmation of thein situ hybridization data and indicates an apparent absolute Riplp requirement for heat shock RN A transport at $42^{\circ} \mathrm{C}$. It is interesting to note that there is no detectable Riplp requirement for heat shock protein synthesis at $37^{\circ} \mathrm{C}$ (lanes 5,6).

The $\left[{ }^{35} \mathrm{~S}\right]$ methionine-label ing experiment (Fig. 1) al so shows that the synthesis of heat shock proteins at both $37^{\circ} \mathrm{C}$ and $42^{\circ} \mathrm{C}$ is accompanied by the disappearance of a number of proteins normally synthesized at $25^{\circ} \mathrm{C}$ (Fig. 1, cf. lanes 1 and 3; the most prominent bands are indi cated 
Figure 1. (A) Analysis of heat shock protein synthesis in wild-type and $\triangle \mathrm{RIP1}$ strains. Cultures of wild-type (WT) or $\Delta R I P 1(\Delta R)$ strains were preheated for 15 min and subsequently labeled for $15 \mathrm{~min}$ with $\left[{ }^{35} \mathrm{~S}\right] \mathrm{methionine}$ at the indicated temperatures. Total protein extracts were fractionated by SDS-PAGE and autoradiographed. The positions of the high-molecular-weight heat shock proteins (Hsp104p, $\mathrm{H}$ sp82p, and the H sp70 proteins Ssalp and Ssa4p) are indicated. Asterisks (*) correspond to non-heat shock bands that persist at $42^{\circ} \mathrm{C}$ in the $\triangle R I P 1$ strain. (B) Heat shock RN A levels in wild-type and $\triangle R I P 1$ strains. Total RN A from wild-type (WT, lanes 1-3) or $\triangle$ RIP1 (lanes 4-6) cultures grown at $25^{\circ} \mathrm{C}$ or shifted to $37^{\circ} \mathrm{C}$ or $42^{\circ} \mathrm{C}$ for $30 \mathrm{~min}$ was analyzed by primer extension with a primer specific for the HSP104 heat shock mRNA. A primer specific for U2 snRNA was used in the same reactions as an internal control for loading. The reactions were fractionated on a denaturing polyacrylamide gel and autoradiographed. The positions of the HSP104 and U2 RNA primer extension products are indicated.

by asterisks). Interestingly, these bands persist at $42^{\circ} \mathrm{C}$ in the $\Delta$ RIP1 strain. The synthesis of these proteins also persists for at least $45 \mathrm{~min}$ in the RNA polymerase II temperature-sensitive mutant rpb1-1 (N onet et al. 1987) after a shift to $42^{\circ} \mathrm{C}$ (data not shown). This observation suggests that these proteins correspond to long-lived cytoplasmic RN As rather than to newly synthesized and recently exported transcripts. In a wild-type strain at $42^{\circ} \mathrm{C}$, the translation of these transcripts is most likely competed by the heat shock RNAs.

To determine whether the block in heat shock RNA export in $\triangle$ RIP1 was accompanied by changes in heat shock RN A levels, primer extension analysis was used to examine the RN As encoding Hsp104p in wild-type or $\triangle \mathrm{RIP1}$ cells after a 30 -min temperature shift (Fig. 1B). HSP104 RNA was undetectable at $25^{\circ} \mathrm{C}$, and virtually identical HSP104 RN A levels were observed in the wildtype and mutant strains at $37^{\circ} \mathrm{C}$; at $42^{\circ} \mathrm{C}$, the HSP104 mRNA levels were three to four times lower in the $\triangle$ RIP1 compared with the wild-type strain (cf. lanes 2 and 5 , or 3 and 6). This modest decrease is likel y to result from a higher turnover of these RN As when sequestered within the nucleus of the $\triangle$ RIPI strain.

Heat shock RNA export at $42^{\circ} \mathrm{C}$ is sensitive to low levels of Riplp and is not dependent on the FG-repeat domain of Riplp

To define more precisely the Riplp requirement in heat shock RNA export, we compared different Riplp-expressing plasmids for their ability to restore heat shock RNA export after transformation into a $\triangle R I P 1$ strain. Construct RIP1-Lo (low) contains the RIP1 gene on an $\sim 1.9-\mathrm{kb}$ genomic fragment with only 380-bp 5'-flanking sequences (Fig. 2A); Western blot analysis indicates that this construct expresses five to ten times lower levels of Riplp than a wild-type strain (Fig. 2B, cf. lanes 1 and 3; note that lane 1 is slightl y overloaded compared with the other lanes). Construct RIP1-Hi (high) contains the RIP1 gene on a 3.5-kb Hindlll genomic fragment with 780-bp 5 '-flanking sequences (Fig. 2A); this plasmid expresses nearly wild-type levels of Riplp (Fig. 2B, cf. Ianes 1 and 4). As expected, the latter construct fully rescues heat shock RNA export when transformed into the $\triangle \mathrm{RIPI}$ strain, as assayed by $\left.{ }^{35} \mathrm{~S}\right]$ methionine labeling of heat shock proteins after a shift to $42^{\circ} \mathrm{C}$ (Fig. 2C, lane 4). In contrast, no heat shock protein synthesis is observed in the presence of the low Riplp-expressing plasmid RIP1Lo (Fig. 2C, lane 3). The data indicate a requirement for minimum levels of Riplp for heat shock RNA export at $42^{\circ} \mathrm{C}$.

The rescue of heat shock protein synthesis with plasmid RIP1-Hi was used as an assay to define the regions of Riplp that are essential for function. To this end, deletions were created within the Riplp coding region of construct RIP1-Hi (Fig. 2A). In construct RIP1-1FG, codons 38 through 364 were deleted and replaced by a Sall linker; this construct encodes a 104-amino-acid protein that lacks all the FG repeats except for one FG dipeptide at positions 4 and 5 of Riplp (Fig. 3A). In construct RIP1-OFG, codons 2 through 364 were deleted and replaced by a Xhol linker; this plasmid encodes a 68amino-acid protein from which all the FG repeats have been eliminated (Fig. 3A). The RIP1-1FG and RIP1-0FG plasmids were introduced into a $\triangle R I P 1$ strain, and heat shock protein synthesis was assayed at $42^{\circ} \mathrm{C}$. Surprisingly, the RIP1-1FG construct efficiently rescued heat shock RNA export, as indicated by the potent induction 
A

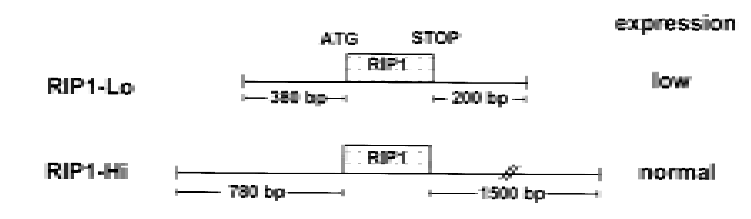

B

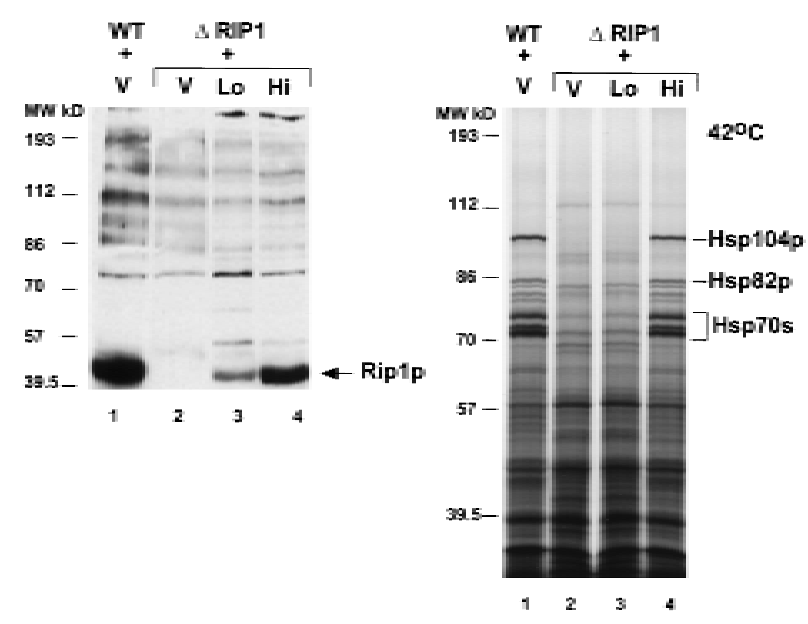

Figure 2. (A) Schematics of RIP1 constructs. The RIP1-Lo (pFS724) and RIP1-Hi (pFS398) constructs contain the RIP1 gene with $380 \mathrm{bp}$ and $780 \mathrm{bp}$ of $5^{\prime}$-flanking sequences, respectively, on a centromeric plasmid. (B) Riplp level s in a wild-type (WT) or in a $\triangle$ RIP1 strain transformed with Riplp-expressing constructs. Total protein extracts were prepared from a wildtype strain transformed with vector p366 al one (WT +V) (lane $1)$, or from the $\triangle$ RIP1 strain transformed with vector $(V)$, the RIP1-Lo (Lo), or the RIP1-Hi (Hi) centromeric constructs (lanes 2-4) and fractionated on a 10\% SDS-polyacrylamide gel; Riplp was detected by Western bl ot analysis using a rabbit anti-Riplp polyclonal antibody directed against the FG-repeat region of Riplp. (C) Rescue of heat shock protein synthesis in the_ $\Delta$ RIP1 strain by the Riplp-expressing plasmids. Cultures from the wild-type strain transformed with vector $(\mathrm{WT}+\mathrm{V})$, or with the $\triangle$ RIP1 strain transformed with vector (V), the RIP1-Lo (Lo), or the RIP1-Hi (Hi) centromeric constructs, were preheated for 15 min at $42^{\circ} \mathrm{C}$ and subsequently labeled with $\left[{ }^{35}\right.$ S]methionine for $15 \mathrm{~min}$ at $42^{\circ} \mathrm{C}$. Total protein extracts were fractionated by SDS-PAGE and autoradiographed.

of heat shock proteins (Fig. 3B, lane 3). The RIP1-OFG protein rescued export very poorly when expressed from a centromeric plasmid (lane 4) but was fully functional when expressed from a high-copy 2 - $\mu \mathrm{m}$ plasmid (lane 5 ). This suggests that the 68-amino-acid protein is active but probably less stable than the 104-amino-acid protein encoded by RIP1-1FG. We have been unable to detect the truncated Riplp proteins by Western blot analysis with a polyclonal antibody directed against the carboxyl terminus of Riplp or by HA-tagging the mutant proteins (data not shown). One possibility is that the truncated proteins are degraded during the extraction procedure; al ternatively or in addition, these anti body reagents may be less sensitive than the rabbit polyclonal antibody spe- cific for the FG repeats of Riplp (Fig. 2B). However, we have been able to detect a biologically active fusion protein between RIP1-OFG and GFP (green fluorescent protein; not shown). A high-copy number plasmid expressing only the FG-repeat region of Riplp (Stutz et al. 1995) was unable to rescue heat shock protein synthesis in a RIP1 deletion strain (data not shown). All the data indicate that overproduction of the short unique Riplp carboxy-terminal domain is sufficient to support robust heat shock RNA export at $42^{\circ} \mathrm{C}$.

The carboxyl terminus of Riplp is important for Rev-mediated RNA export

We have shown previously that Rev promotes the export of RRE-containing transcripts in yeast. In this assay,
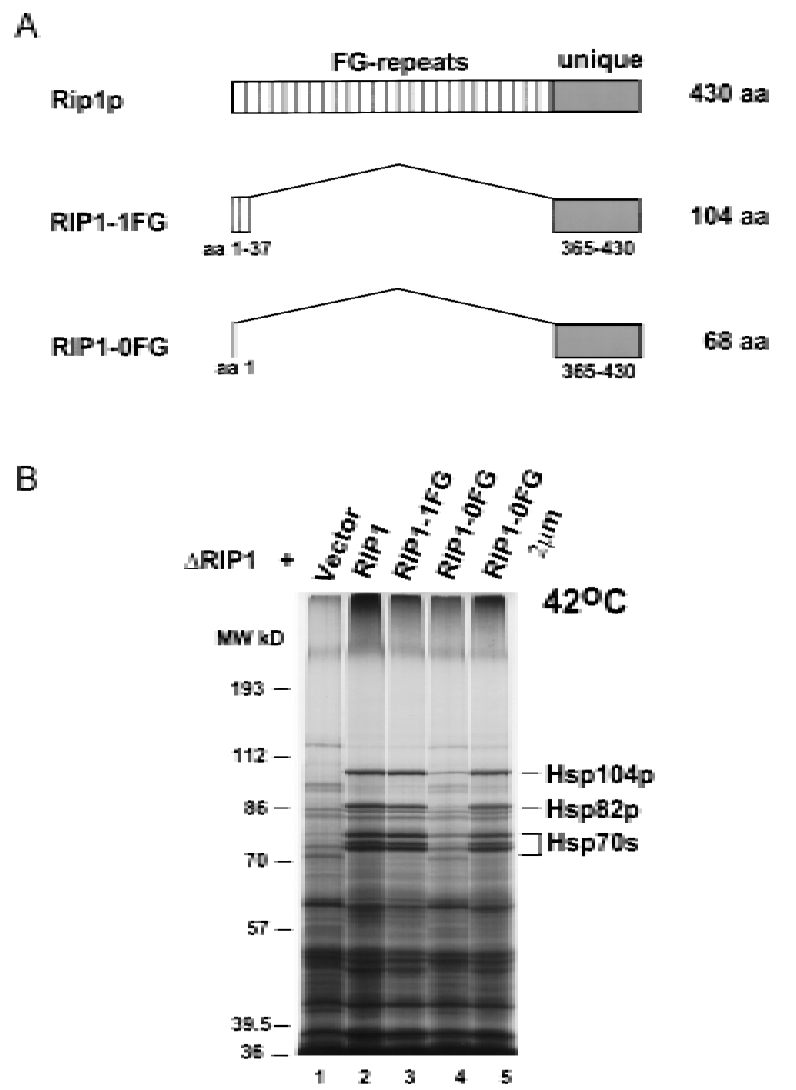

Figure 3. (A) Schematic drawing of full-length Riplp and the deleted Ripl proteins encoded by the RIP1-1FG (pFS662) and RIP1-0FG (pFS730 and pFS733) constructs. The lengths of the proteins are indicated at right. The FG-repeat region and the unique region of Riplp are represented by striped and shaded boxes, respectively. The amino acids contained in the deleted proteins are indicated below. The RIP1-1FG protein contains a single FG dipeptide at amino acid positions 4 and 5 . (B) The unique carboxyl terminus of Riplp rescues heat shock protein synthesis at $42^{\circ} \mathrm{C}$ in the $\triangle \mathrm{RIPI}$ strain. The $\Delta \mathrm{RIP} 1$ strain was transformed with vector alone (V, lane 1 ) or with the Riplpexpressing constructs RIP1-Hi (pFS398, lane 2), RIP1-1FG (FS662, lane 3), RIP1-0FG (pFS730, lane 4), or RIP1-OFG $2 \mu$ (pFS733, lane 5). Heat shock protein synthesis at $42^{\circ} \mathrm{C}$ was analyzed as described in Fig. 2. 
Rev's activity is monitored by changes in the copper resistance of an engi neered yeast strain (Stutz and Rosbash 1994). This copper-sensitive strain contains a Revexpressing plasmid and a CUP1 reporter plasmid (PCCUP-RRE). The transcripts generated by the PC-CUPRRE plasmid contain the CUP1 coding sequence interrupted at its $5^{\prime}$ end by a small in-frame intron (Legrain and Rosbash 1989), foll owed by the RRE after the CUP1 stop codon. The CUP1 protein is encoded only from the pre-mRNA (the spliced mRNA is out-of-frame) so that the copper resistance of this reporter strain directly reflects the levels of cytoplasmic pre-mRN A. In the presence of wild-type Rev, the reporter strain grows in up to $1.2 \mathrm{~mm}$ copper, whereas it grows up to $0.8 \mathrm{~mm}$ copper with no Rev or with the Rev M10 mutant. (Rev M10 contains a mutation in the NES that inhibits Rev's export activity; Table 1). These Rev effects on yeast premRN A export parallel the Rev effects on viral gene expression in mammalian cells (Stutz et al. 1995).

As reported previously, the Rev-mediated copper resistance is reduced to $1 \mathrm{~mm}$ copper in the $\Delta \mathrm{RIP} 1$ strain, indicating a contribution of Riplp to Rev-mediated export (Stutz et al. 1995). To determine which region of Riplp is involved in Rev function, constructs expressing total Riplp or truncated versions of the Riplp protein were introduced into the $\triangle$ RIP1 strain together with the PC-CUP-RRE reporter construct and a plasmid expressing wild-type Rev. The full-length RIP1 construct (RIP1$\mathrm{Hi}$ ) increased copper resistance to $1.2 \mathrm{~mm}$; RIP1-1FG and the $2-\mu \mathrm{m}$ version of RIP1-0FG increased copper resistance to $1.1 \mathrm{~mm}$, indicating substantial rescue, whereas the centromeric RIP1-0FG had no effect (Table 1). This indicates that the carboxyl terminus of Riplp contributes to Rev-mediated export as well as to heat shock mRN A export. The lack of a major role for the FG-repeat region of Riplp is surprising (see Discussion).

\section{Relationship of Riplp to the nuclear pore and to Glelp}

Previous immunolocalization experiments suggested that Riplp is associated with the NPC, which is also consistent with its sequence features. To confirm this notion, we used a biochemical approach to address
Riplp's subcellular localization. In this fractionation procedure (Fig. 4), Riplp is undetectable in the low-speed supernatant (S) of a total cell lysate (in which $>50 \%$ of the nuclei are lysed) and is released from the pellet by extraction with $1 \mathrm{M} \mathrm{NaCl}(P)$. The behavior of Riplp in this assay is identical to that described for other nuclear pore proteins (Bel anger et al. 1994). The observations are consistent with the association of the majority of Riplp protein with the N PC.

To identify components genetically related to Riplp, we isolated mutations that are lethal in the absence of Riplp (Bender and Pringle 1991; see M aterial s and M ethods). One of the identified genes encodes $\mathrm{N}$ up85p (data not shown), a nuclear pore protein with a role in poly $(A)^{+}$ RNA export (Goldstein et al. 1996; Siniossoglou et al. 1996). Although incomplete at present, this synthetic lethal screen also gave rise to a high proportion (75\%) of mutants that mapped to the previously defined mRNA export mediator Glelp (Del Priore et al. 1996; Murphy and Wente 1996). This result provides genetic evidence that Riplp, like Glelp, contributes to mRN A export.

Three of the Glel alleles identified in this screen (glel1, gle1-2, and gle1-3) were chosen at random and characterized in more detail. These three al leles affect Glelp function to different extents, because they exhibit different growth phenotypes in the presence of wild-type levels of Riplp (Table 2). With different RIP1-rescuing plasmids, there was an effect on nuclear retention of poly $(A)^{+}$ RNA as well as on growth rate; both of these phenotypes were exacerbated in the Glel mutants by limiting levels of Riplp (data not shown; Table 2). Some poly(A)+RN A nuclear staining was al so observed in the presence of Iow levels of Riplp at $25^{\circ} \mathrm{C}$. The mutations in glel-1, glel-2, and glel-3 were all determined to be amino acid substitutions in the carboxy-terminal part of Glelp, beyond the proposed NES (Table 2; Fig. 5A). This identifies a novel and unanticipated domain of Glelp, as previous results from others had focused on the N ES-like regi on of Glelp that is important for its interaction with nuclear pore FG repeats (M urphy and Wente 1996). The NES mutation L356A in Glelp (M urphy and Wente 1996) is al so lethal in the absence of Riplp (data not shown).

Interestingly, all three Glel mutants were rescued by

Table 1. The carboxyl terminus of Riplp is important for Rev-mediated RNA export

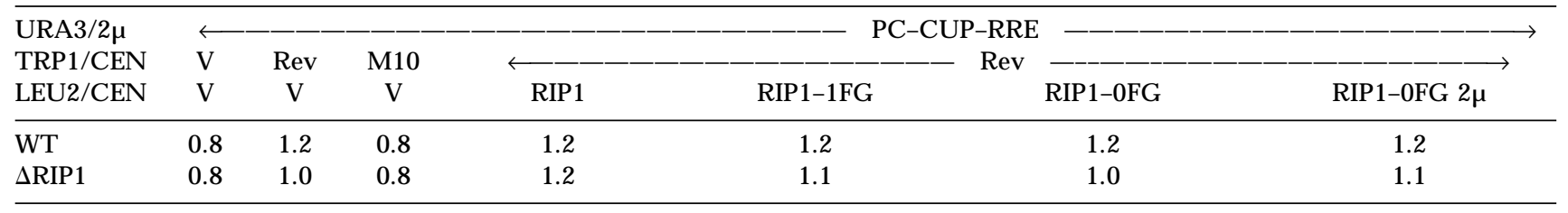

Rev-mediated RN A export is reflected by an increase in the copper resistance of the yeast reporter strain. WT (Y59ACUP) or $\Delta$ RIP1 (Y59 $D$ CUPARIP1) strains were transformed with the PC-CUP-RRE reporter plasmid (URA3/2 $\mu$ ) and with Rev-expressing plasmids (TRP1/CEN) as described earlier (Stutz et al. 1995). In the wild-type strain (WT), the export of the PC-CUP-RRE transcript is stimulated by Rev and results in an increase of copper resistance. This effect is weakened in the $\Delta$ RIP1 strain.

The rescue of Rev-mediated export was examined by transforming both strains with the Riplp-expressing plasmids pFS398 (RIP1), pFS662 (RIP1-1FG), pFS730 (RIP1-0FG CEN), or pFS733 (RIP1-0FG $2 \mu$ ) or with empty vector controls (V). The transformed strains were grown to saturation and spotted onto $\mathrm{Ura}^{-} \mathrm{Leu}^{-} \mathrm{Trp}^{-}$plates containing increasing concentrations of $\mathrm{CuSO}_{4}$. The numbers correspond to the copper resistance $\left[\mathrm{Cu}^{2+}(\mathrm{mm})\right]$ of each transformed strain. 


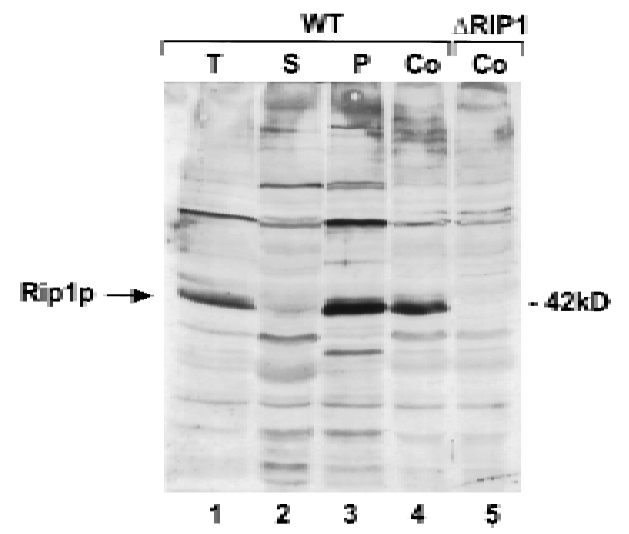

Figure 4. Riplp is part of an insoluble and salt labile highmolecular-weight complex. Wild-type yeast cells were fractionated as described in Materials and M ethods. The soluble fraction (S) represents proteins released into a low-speed supernatant after cell lysis. The particulate fraction (P) represents material released from the low-speed pellet by extraction with buffer containing $1 \mathrm{M} \mathrm{N} \mathrm{aCl}$. All the nucleoporins are solubilized under these conditions (Belanger et al. 1994). Aliquots of total (T) cell Iysate $\left(0.15 \mathrm{OD}_{600}\right.$ cells; lane 1$)$, fraction $\mathrm{S}\left(2.4 \mathrm{OD}_{600}\right.$ cells; lane 2$)$, or fraction $\mathrm{P}\left(3 \mathrm{OD}_{600}\right.$ cells; Iane 3 ) were subjected to Western blot analysis with a mouse polyclonal antibody directed against the unique carboxyl terminus of Riplp. The Riplp protein was identified by parallel analysis of control (Co) total cell extracts prepared from a wild-type (WT; lane 5) or the $\Delta$ RIP1 (lane 6) strain by TCA precipitation.

the RIP1-OFG 2- $\mu$ m construct nearly as well as by fulllength Riplp (RIP1 high), suggesting that the carboxyl terminus of Riplp is also relevant to its genetic interaction with Glelp (Table 2). The three mutants were al so viable in the presence of limiting amounts of full-length Riplp (RIP1 low), al though growth at $25^{\circ} \mathrm{C}$ was marginally affected in the case of the more severe glel-1 and gle1-3 alleles (not shown). Taken together with the previously defined role of Glelp in poly $(A)^{+}$RNA export (Del Priore et al. 1996; Murphy and Wente 1996), the genetic interactions suggest that the carboxy-terminal domain of Riplp is al so the primary region of Riplp contributing to this export pathway. The genetic interactions may reflect a physical interaction as indicated by yeast two-hybrid interaction between wild-type Glelp and the carboxy-terminal domain of Riplp as well as by in vitro interactions of various Riplp-GST fusions with reticulocyte lysate-translated Glelp (data not shown).

The Glel mutants allow heat shock RNA export in the presence of limiting amounts of Riplp

Given the genetic relationship between Glelp and Riplp, the role of Glelp in poly $(A)^{+}$RN A export, and the important role of Riplp in heat shock RN A export, it was also of interest to determine whether Glelp manifests any detectable role in heat shock RN A export. We therefore assayed heat shock protein synthesis at $42^{\circ} \mathrm{C}$ in the three Glel mutant strains, in the presence of normal or low levels of Riplp. As described above, low (Lo) levels of Riplp prevent heat shock RN A export in an otherwise wild-type background (Fig. 5, lane 3; Fig. 2). Interestingly, this heat shock RN A export defect was suppressed in the presence of all three Glel mutant alleles: Synthesis of Hsp104p and to a lesser extent Hsp82p and Ssa4p was substantially rescued after a shift to $42^{\circ} \mathrm{C}$ (Fig. $5 \mathrm{~B}$, cf. lane 3 with lanes 5, 7, and 9). With normal ( $\mathrm{Hi})$ Riplp levels, heat shock protein synthesis at $42^{\circ} \mathrm{C}$ in the three Glel mutant strains was comparable with that observed in the wild-type GLE1 background (Fig. 5B, cf. lane 4 with lanes 6,8 , and 10). Rather than defining a strong role for Glelp in heat shock RN A export, the data suggest that there is competition between the apparently Glelp-dependent poly $(\mathrm{A})^{+}$RNA export pathway and the apparently Riplp-dependent heat shock RNA export pathway: The Glel mutants weaken the poly $(A)^{+}$RNA export pathway thus allowing heat shock RN A export to occur even in the presence of li miting amounts of Riplp (Fig. 6).

\section{Discussion}

As discovered by Saavedra et al. (1997), the selective export of heat shock RN As at $42^{\circ} \mathrm{C}$ is affected by deletion of the RIP1 gene. Our biochemical results fully confirm these in situ hybridization observations and indicate that the effect is robust. As RIP1 is an inessential gene for growth at normal temperatures, the different obser-

Table 2. Rescue of the RIP1 synthetic lethal alleles of GLE1 with different RIP1 constructs

\begin{tabular}{lccccccccccccc}
\hline & \multicolumn{10}{c}{ Growth } \\
\cline { 2 - 11 } gle1 mutant & Mutation & $\left(25^{\circ} \mathrm{C}\right)$ & $\left(37^{\circ} \mathrm{C}\right)$ & $\left(25^{\circ} \mathrm{C}\right)$ & $\left(37^{\circ} \mathrm{C}\right)$ & $\left(25^{\circ} \mathrm{C}\right)$ & $\left(37^{\circ}\right)$ & $\left(25^{\circ} \mathrm{C}\right)$ & $\left(37^{\circ} \mathrm{C}\right)$ & $\left(25^{\circ} \mathrm{C}\right)$ & $\left(37^{\circ} \mathrm{C}\right)$ & $\left(25^{\circ} \mathrm{C}\right)$ & $\left(37^{\circ} \mathrm{C}\right)$ \\
\hline gle1-1 & F381S & - & - & + & + & + & slow & + & very slow & + & - & + & very slow \\
gle1-2 & T468I & - & - & + & + & + & + & + & + & + & - & + & + \\
glel-3 & M 3981 & - & - & + & - & + & - & + & - & + & - & + \\
\hline
\end{tabular}

The mutation in each of the three Glel mutants is shown; the growth of the Glel mutant strains in the presence of different Riplp-expressing plasmids was examined by replacing the screening plasmids pFS652 or pFS478 (URA3/ADE3/CEN) with the following LEU 2/CEN plasmids: p366 vector (no RIP1), pFS398 (RIP1 high), pFS724 (RIP1 low), pFS662 (RIP1-1FG), pFS730 (RIP1-0FG) or with the LEU $/ 2 \mu$ construct pFS733 (RIP1-OFG). The phenotype of these strains was examined by growth on Leu ${ }^{-}$plates at $25^{\circ} \mathrm{C}$ or $37^{\circ} \mathrm{C}$. 
A

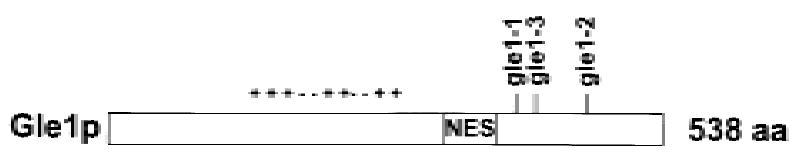

B

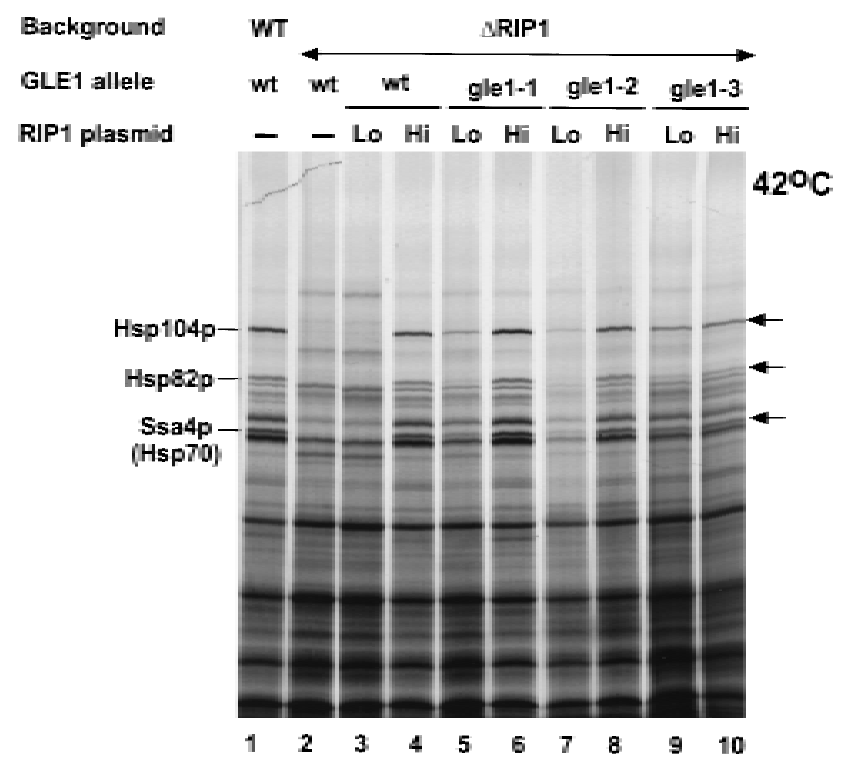

Figure 5. (A) Schematic drawing of the Glel protein. The positions of the three Glel mutations (glel-1, glel-2, and glel-3) that are synthetically lethal with a RIP1 deletion are indicated. The N ES (amino acid positions 351-356) is boxed. $(+t-$ A central domain rich in charged residues. (B) The Glel mutations synthetically lethal with a RIP1 deletion restore heat shock protein synthesis at $42^{\circ} \mathrm{C}$ in the presence of low amounts of Riplp. Heat shock protein synthesis at $42^{\circ} \mathrm{C}$ was assayed as in Fig. 2C. Lanes 1 and 2 correspond to wild-type and $\Delta$ RIP 1 strains transformed with the p366 vector alone; lanes 3, 5, 7, and 9 correspond, respectively, to the $\triangle \mathrm{RIP} 1$, glel-1, glel-2, and glel-3 strains carrying construct RIP1-Lo (Lo) and expressing low levels of Riplp (Fig. 2A); Ianes 4, 6, 8, and 10 correspond, respectively, to the $\triangle$ RIP1, gle1-1, glel-2, and gle1-3 strains carrying construct RIP1-Hi $(\mathrm{Hi})$ and expressing high levels of Riplp (Fig. 2),

vations make a strong case that Riplp is only an essential component of the heat shock mRN A transport pathway. This implies that the heat shock and cellular (i.e., non-heat shock) mRNA transport pathways are distinct. Consistent with this notion, factors such as Gsplp (a small GTPase) and its effectors Rnalp and Prp20p (the GAP and nucleotide exchange factors for Gsplp, respectively) are requi red for general RNA transport (Koepp and Silver 1996; Corbett and Silver 1997) but dispensable for heat shock mRN A export (Saavedra et al. 1996).

Interestingly, heat shock mRNA transport is not dependent on Riplp at $37^{\circ} \mathrm{C}$. This might reflect a more transient and less severe heat shock response at this lower and more physiological temperature. Experiments from the Cole laboratory suggest that the Riplp dependence is not restricted to temperature but is a more general response to stress conditions (Saavedra et al. 1997). These must alter heat shock mRN P and/or the nuclear pore so that a role for Riplp is revealed. Stress does not seem to affect Riplp, as we have been unable to detect any obvious temperature-induced change in protein levels or mobility by Western blot analysis (data not shown).

A contribution of Riplp to selective RN A transport recalls the discovery of this protein as a mediator of Revdependent RNA transport in yeast: The FG-repeat domain of Riplp shows a yeast two-hybrid interaction with the NES in Rev and a deletion or over-expression of Riplp-affected Rev-mediated RNA export (Stutz et al.

A WT Ripip $\quad$ STRESS

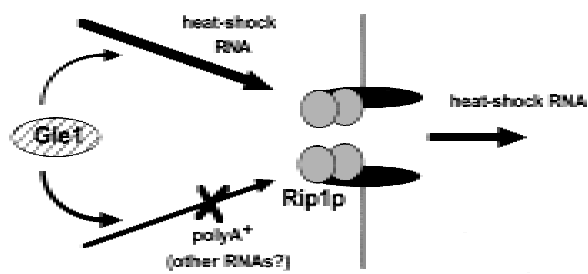

B Low or no Riplp
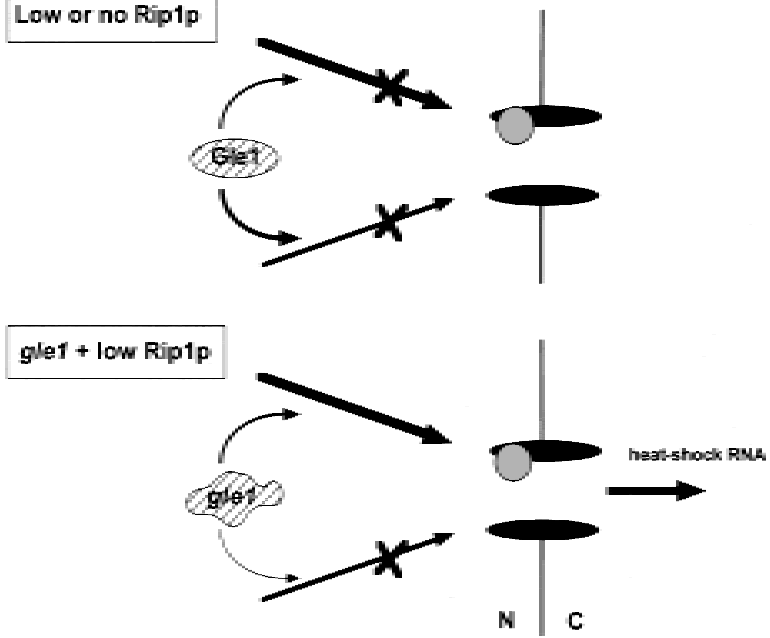

Figure 6. Model for heat shock RN A and poly $(A)^{+}$RN A export under stress conditions. (A) In a wild-type strain, stress allows efficient export of heat shock RNAs but inhibits the export of poly(A) ${ }^{+}$RN A (Saavedra et al. 1996). Both Glelp and Riplp are involved in heat shock RN A export (under stress) and poly $(A)^{+}$ RNA export (under normal conditions). Glelp is essential for poly $(A)^{+}$RNA export but also participates in heat shock RNA export. Riplp is essential for heat shock RNA export but also contributes to poly $(A)^{+}$RNA export. It is proposed that heat shock and poly(A) $)^{+}$RN As compete for access to Glelp. (B) No heat shock RN A export is observed with low or no Riplp. (C) Mutant Glelp affects poly $(A)^{+}$RN A export more strongly than heat shock RNA export, perhaps because mutant alleles are more deleterious to the interaction with poly $(A)^{+}$RN Ps than that with heat shock RN Ps. The increased availability of Glelp then al lows heat shock RN A export in the presence of limiting amounts of Riplp. 
1995). As coexpression of Rev manifests a partial inhibition of heat shock mRN A transport as assayed by in situ hybridization (Saavedra et al. 1997), a Rev-like NES sequence probably mediates the nuclear export of heat shock mRN As. Although this might indicate an involvement of Riplp FG repeats, Riplp carboxy-terminal region fully rescues heat shock RN A transport and at least partially rescues Rev-medi ated transport. This is surprising and, at a minimum, suggests a redundant contributi on of other FG repeat-containing nucleoporins. Consistent with this possibility, other FG nucleoporins bind credibly to Rev and Rev-like NES sequences in the twohybrid assay (Stutz et al. 1995, 1996; Fritz and Green 1996). Moreover, there is evidence that the interaction between Rev and Rip FG repeats may be indirect (N eville et al. 1997). Therefore, we suspect that this unique region of the protein contributes to pore function rather than binding directly to RNA or to an RNA-relevant NES.

Y et Riplp appears to contribute preferentially to an RNA export function. This view is based in part on the synthetic lethal relationship between a RIP1 deletion and mutants in other cellular components implicated in general poly $(A)^{+}$RN A transport. Glel temperature-sensitive allel es, in particular, have strong and rapid effects on poly $(A)^{+}$RNA retention within nuclei, consistent with the proposed role of this protein as a mediator of mRN A transport (Murphy and Wente 1996). Also, mutations in N up82p (L. Davis, unpubl.) and in N up85p (our screen; data not shown) are synthetic lethal with a RIP1 del etion; both of these nuclear pore proteins are invol ved in poly (A ) ${ }^{+}$RN A export (Grandi et al. 1995; Hurwitz and Blobel 1995; Goldstein et al. 1996; Siniossoglou et al. 1996). We suggest, therefore, that the export of poly(A) ${ }^{+}$ RNA is suboptimal through Riplp-deficient pores, but this is normally not limiting for growth; in combination with any of the three Glel missense mutations, however, poly $(A)^{+}$RNA export becomes too low to support viability (Table 2). This is also consistent with the poly $(A)^{+}$retention phenotype of all three Glel alleles, which is enhanced in combination with low Riplp levels. We cannot, however, exclude the possi bility that the genetic relationship between RIPI and GLEI reflects the transport of a small, specific subset of the poly $(A)^{+}$RN A population or of other classes of RN As (i.e., $U$ snRN As or 5S RNAs), which have features in common with heat shock mRN P substrates.

If Riplp is a component of the poly $(A)^{+}$as well as the heat shock RNA export pathway, both sets of substrates must compete for access to shared components. The experiment in Figure 5 suggests that the Glel mutants depress non-heat shock mRNA transport and thereby restore detectable levels of heat shock RN A transport and heat shock protein synthesis in the presence of limiting amounts of Riplp (Fig. 6). The results are hard to understand unless the role of Glelp in normal poly $(A)^{+}$RN A transport is more important than any role it may play in heat shock mRNA transport. However, we cannot exclude the possibility that the observations reflect allelespecific effects of the three Glel mutants, and we note that Saavedra et al. (1997) show that a temperature-sensitive Glel mutant (rss1-37) interferes with heat shock as well as poly $(A)^{+}$mRN A export.

Riplp, in contrast, is clearly more important for heat shock mRN A export than for poly $(A)^{+}$mRNA export. In addition to the arguments described above, the rescue of the Glel synthetic lethal mutants with low levels of Riplp (Table 2) suggests that the requi rement for cell ular RNA transport is fulfilled with minimal Riplp levels. These same low levels of Riplp do not suffice for detectable heat shock mRN A transport (Fig. 2).

Riplp contributes to different pathways, indicating that different substrates must compete for access to the shared components of a universal nuclear pore. Yet the substrates are affected differentially by the physiological and genetic manipulations. It follows that stress must reduce the transport efficiency of non-heat shock mRNAs more than that of heat shock mRNAs, which indicates a difference in the two classes of RN P structures under these conditions (Saavedra et al. 1996). Incubation at $42^{\circ} \mathrm{C}$ could decrease transport efficiency by affecting the mRN $P$ substrates or the pore. Adequate RN A transport may then require an otherwise fully functional pore for the expression of normal or near-normal levels of heat shock proteins. This transport efficiency view would explain the apparently sel ective role of Riplp in heat shock mRNA transport: An essential role is revealed only under stress conditions, when transport is more generally compromised. Similarly, the generic contribution of Riplp to non-heat shock RNA export at $25^{\circ} \mathrm{C}$ becomes apparent only in the presence of additional mutant alleles (i.e., Glel alleles) that reduce the efficiency of RNA transport.

This interpretation is similar to a contemporary view of pre-mRNA splicing, in which a fundamentally generic set of spliceosome components processes substrates with a range of efficiencies; less efficient substrates more easily reveal contributions from a larger number of factors (Liao et al. 1993; Stutz et al. 1997). A nother lesson from the more completely understood splicing pathway as well as the protein import pathway is that in vitro bi ochemistry will be required to clarify the contribution of individual components to the RNA export process.

\section{Materials and methods}

The DN A manipulations were performed according to standard methods (M aniatis et al. 1982; A usubel et al. 1994); yeast media and yeast transformations were performed with standard procedures (Guthrie and Fink 1991). The strains and plasmids used in this study are described in Table 3.

\section{Plasmid constructions}

Plasmid pFS398 (RIP1-Hi) contains a genomic 3.5-kb RIP1 HindlII fragment with $0.78-k b 5^{\prime}$-flanking sequences (Stutz et al. 1995) inserted into the HindllI site of vector p366 (LEU 2/ CEN). pFS724 (RIP1-Lo) contains the RIP1 gene on a 1.9-kb HindlII PCR fragment with $0.38-k b$ 5'-flanking sequences inserted into the HindIII site of p366. The RIP1 deletion mutant constructs pFS662 and pFS730, encoding RIP1-1FG and RIP1- 
Table 3. Strains and plasmids used in this study

\begin{tabular}{|c|c|c|}
\hline Strain & Genotype & Reference \\
\hline W303 & ade2 his3 leu2 trp1 ura3 MATa & \\
\hline W303ARIP1 & ade2 his3 leu2 trp1 ura3 MATa ripl::KAN ${ }^{R}$ & this study \\
\hline Y59 CUP & ade2 arg4 leu2 trp1 ura3 Mata $\Delta$ CU P1 & Stutz et al. (1995) \\
\hline Y59 4 CUPARIP1 (FSY2) & ade2 arg4 leu2 trp1 ura3 Mata $\Delta$ CU P1 $\Delta$ RIP1 & Stutz et al. (1995) \\
\hline $\mathrm{CH} 1305$ & ade2 ade3 leu2 ura3 Iys2 can1 MATa & Holm (1993) \\
\hline CH1305 $\Delta$ RIP1 (FSY5) & ade2 ade3 leu2 ura3 lys2 can1 MATa $\Delta$ RIP1 & this study \\
\hline FSY 56 & ade2 ade3 leu2 ura3 lys2 can1 MATa $\Delta$ RIP1 carrying pFS652 & this study \\
\hline CH1462 & ade2 ade3 leu2 ura3 his3 MAT $\alpha$ & Holm (1993) \\
\hline $\mathrm{CH} 1462 \Delta \mathrm{RIP1}$ (FSY6) & ade2 ade3 leu2 ura3 his3 MAT $\alpha \Delta$ RIP1 & this study \\
\hline FSY 13 & ade2 ade3 leu2 ura3 his3 MAT $\alpha \Delta$ RIP1 carrying pFS478 & this study \\
\hline FSY 14 & ade2 ade3 leu2 ura3 his3 MAT $\alpha \Delta$ RIP1 carrying pFS652 & this study \\
\hline FSY 15 & ade2 ade3 leu2 ura3 his3 MAT $\alpha \Delta$ RIP1 glel-1 carrying pFS478 & this study \\
\hline FSY 16 & ade2 ade3 leu2 ura3 his3 MAT $\alpha \Delta$ RIP1 gle1-1 carrying pFS652 & this study \\
\hline FSY 20 & ade2 ade3 leu2 ura3 Iys2 can1 MATa $\Delta$ RIP1 glel-2 carrying pFS652 & this study \\
\hline FSY 23 & ade2 ade3 leu2 ura3 his3 MAT $\alpha \Delta$ RIP1 gle1-3 carrying pFS652 & this study \\
\hline FSY 57 & ade2 ade3 leu2 ura3 his3 MAT $\alpha \Delta$ RIP1 gle1-1 carrying pFS724 & this study \\
\hline FSY 58 & ade2 ade3 leu2 ura3 his3 MAT $\alpha \Delta$ RIP1 gle1-1 carrying pFS398 & this study \\
\hline FSY 59 & ade2 ade3 leu2 ura3 Iys2 can1 MATa $\Delta$ RIP1 glel-2 carrying pFS724 & this study \\
\hline FSY 60 & ade2 ade3 leu 2 ura3 Iys2 can1 MATa $\triangle$ RIP1 gle1-2 carrying pFS398 & this study \\
\hline FSY 61 & ade2 ade3 leu2 ura3 his3 MAT $\alpha \Delta$ RIP1 glel-3 carrying pFS724 & this study \\
\hline FSY 62 & ade2 ade3 leu2 ura3 his3 MAT $\alpha \Delta$ RIP1 gle1-3 carrying pFS398 & this study \\
\hline FSY 65 & ade2 ade3 leu2 ura3 his3 MAT $\alpha \Delta$ RIP1 carrying pFS724 & this study \\
\hline FSY 66 & ade2 ade3 leu2 ura3 his3 MAT $\alpha \Delta$ RIP1 carrying pFS398 & this study \\
\hline \multicolumn{3}{|l|}{ Plasmid } \\
\hline p366 (LEU2/CEN) & YCp50-based vector in which URA3 was replaced with LEU 2. & Liao et al. (1993) \\
\hline pFS398 (RIP1-Hi) & $\begin{array}{l}\text { HindlII RIP1 genomic 3.5-kb fragment inserted into the HindlII site of } \\
\text { p366 (LEU 2/CEN ); contains 0.78-kb RIP1 5'-flanking sequences. }\end{array}$ & this study \\
\hline pFS724 (RIP1-Lo) & $\begin{array}{l}\text { HindIII RIP1 1.9-kb fragment generated by PCR inserted into the HindIII } \\
\text { site of p366; contains 0.38-kb RIP1 5'-flanking sequences. }\end{array}$ & this study \\
\hline pFS662 (RIP1-1FG) & deletion of codons 38-364 of RIP1 in pFS398. & this study \\
\hline pFS730 (RIP1-OFG) & deletion of codons $2-364$ of RIP1 in pFS398. & this study \\
\hline pFS733 (RIP1-0FG) & $\begin{array}{l}\text { HindIII } 2.3-\mathrm{kb} \text { insert of pFS730 inserted into the Sall site of JH21 vector } \\
\text { (LEU } 2 / 2 \mu \mathrm{m} \text { ) using Sall linkers. }\end{array}$ & this study \\
\hline pCH1122 & URA3 ADE3 CEN vector. & Holm (1993) \\
\hline pFS652 & $\begin{array}{l}\text { HindIII RIP1 genomic 3.5-kb fragment inserted into the Sall site of pCH1122 } \\
\text { using Sall linkers; contains 0.78-kb RIP1 5'-flanking sequences. }\end{array}$ & this study \\
\hline pFS478 & $\begin{array}{l}\text { HindIII RIP1 1.9-kb fragment generated by PCR inserted into the Sall site of } \\
\text { pCH1122 using Sall linkers; contains 0.38-kb RIP1 5'-flanking sequences. }\end{array}$ & this study \\
\hline
\end{tabular}

OFG, respectively, were generated by PCR using the 3.5-kb insert of pFS398 as a template. pFS662 was obtained by ligation of a 5' HindlII-Sall PCR fragment (from position -780 to codon 37 of RIP1) to a 3' Sall-HindIII PCR fragment (containing codons 365 to the stop of RIP1 and 1.5-kb 3' flanking sequences) and cloning into p366 cut with HindlII. pFS730 was obtained by ligation of a $5^{\prime}$ HindlII-Xhol fragment (from position -780 to codon 1 of RIP1) to a $3^{\prime}$ Xhol-Hindlll fragment (containing codons 365 to the stop and 1.5-kb $3^{\prime}$-noncoding sequences) and cloned into p366 cut with HindlII. pFS733 was obtained by cloning the 2.3-kb HindIII RIP1-OFG insert of pFS730 into the Sall site of vector pJ H21 (LEU $2 / 2 \mu$ ) using Sall linkers.

\section{Yeast strains}

The W303 RIP1 strain was made using a PCR-based disruption procedure with the kanMX2 template (Wach et al. 1994) and two oligonucleotides: 5'-CAAGCTATCA TTAAATTTCG ACCCGAGCAA CGACTCAACT GTAGCCAGCT GAAGCTTCGT ACGCTG-3' and 5'-CTATGCAACC AATGCAGG-
TG GTGGAGGTAT ATCAGGGACA AGGCATAGGC CACTAGTGGA TCTG-3'. This generated a PCR fragment of $\sim 1.4$ $\mathrm{kb}$ containing the Escherichia coli $\mathrm{KAN}^{\mathrm{R}}$ (kanamycin resistance) gene flanked at the $5^{\prime}$ end by $44 \mathrm{bp}$ of sequences from bp -1 to -43 of RIP1 and at the $3^{\prime}$ end by 42 bp of sequences from bp +1251 to the stop of RIP1. One to two micrograms of this PCR fragment was transformed into W303, and transformants were selected on YPD plates containing 200 mg/l G418 (Geneticin, GIBCO BRL). Replacement of the RIP1 gene by the KAN ${ }^{R}$ gene was confirmed by PCR analysis and Southern blotting.

The Y 59 $\Delta$ CUP and Y 59 $\Delta$ CUP $\Delta$ RIP1 (FSY2) strains have been described (Stutz et al. 1995).

In vivo protein labeling

The yeast strains were grown as 15-ml cultures in synthetic complete medium lacking methionine or in the appropriate dropout medium lacking methionine overnight at $23^{\circ} \mathrm{C}$ to an $\mathrm{OD}_{600}$ of $0.05-0.1\left(5.10^{5}-1.10^{6} \mathrm{cel} / \mathrm{s} / \mathrm{ml}\right)$. Cells were collected by centrifugation, resuspended in $0.5-1 \mathrm{ml}$ of medium lacking me- 
thionine and distributed into Eppendorf tubes as $0.25-\mathrm{ml}$ aliquots. These cells were rapidly mixed with one volume of medium lacking methionine preheated to $49^{\circ} \mathrm{C}$ or $59^{\circ} \mathrm{C}$ and incubated at $37^{\circ} \mathrm{C}$ or $42^{\circ} \mathrm{C}$, respectively. The $25^{\circ} \mathrm{C}$ control samples were mixed with one volume of medium at $25^{\circ} \mathrm{C}$. After $15 \mathrm{~min}$, the samples were mixed with $50 \mu \mathrm{Ci}$ of Trans ${ }^{35} \mathrm{~S}$-label (1191 $\mathrm{Ci} / \mathrm{mmole}, 11.02 \mathrm{mCi} / \mathrm{ml}$, ICN Pharmaceuticals, Inc.) and incubated for another $15 \mathrm{~min}$ at the same temperature. Protein labeling was stopped by centrifugation at $4^{\circ} \mathrm{C}$; the cell pellets were washed twice with $1 \mathrm{ml}$ of culture medium in the cold, resuspended in 30-50 $\mu$ of $1 \times$ SDS sample buffer, and immediately frozen on dry ice. The samples were boiled for $10 \mathrm{~min}$ and fractionated on a $8 \%$ SDS-polyacrylamide gel. Gels were dried and autoradiographed.

\section{RNA extractions and primer extensions}

The wild-type (W303) and $\triangle$ RIP1 (W303 2 RIP1) strains were grown overnight in $100 \mathrm{ml}$ of $\mathrm{YPD}$ at $25^{\circ} \mathrm{C}$ to an $\mathrm{OD}_{600}$ of 0.1 $\left(\sim 1.10^{6} \mathrm{cell} / \mathrm{s} / \mathrm{ml}\right)$. Twenty-five-milliliter al iquots of each culture were rapidly mixed with an equival ent volume of $Y P D$ at $25^{\circ} \mathrm{C}$, $49^{\circ} \mathrm{C}$, or $59^{\circ} \mathrm{C}$ and incubated at $25^{\circ} \mathrm{C}, 37^{\circ} \mathrm{C}$, or $42^{\circ} \mathrm{C}$, respectively, for $30 \mathrm{~min}$. RN A extractions and primer extensions were performed according to published procedures (Pikiel ny and Rosbash 1985) using two oligonucl eotide primers. Oligonucleotide primer OFS 191 is complementary to positions +63 to +85 from the ATG of the HSP104 gene. Oligonucleotide primer DT58, which is complementary to U 2 snRN A and gives an 120-base primer extended product, was used as an internal control for loading. Extension products were analyzed on $6 \%$ polyacrylamide denaturing gels (Fig. 1B).

\section{Rev growth assay}

Strains Y59 $A$ CUP and Y59 $A$ CUPARIP1 were transformed with a URA $3 / 2 \mu$ version of the PC-CUP-RRE reporter construct and different Rev-expressing plasmids (TRP1/CEN) as described earlier (Stutz and Rosbash 1994; Stutz et al. 1995). These strains were then transformed with the p366 vector (LEU2/CEN) or with the Riplp-expressing plasmids pFS398, pFS662, pFS730 (LEU2/CEN), or pFS733 (LEU2/2 $\mu$ ). The triple transformants were grown to saturation in selective medium and spotted onto sel ective plates containing increasing concentrations of $\mathrm{CuSO}_{4}$ (from 0.1 to $1.3 \mathrm{~mm}$ with $0.1 \mathrm{~mm}$ increments). The copper resistance of each strain was scored after incubation at $30^{\circ} \mathrm{C}$ for 5 days.

\section{Total cell extracts and cell fractionation}

For total cell extracts, $1 \mathrm{ml}$ of overnight-saturated cultures were spun in an eppendorf tube and the cells were broken with glass beads in $100 \mu$ of cold $20 \%$ trichloroacetic acid (TCA). A TCA precipitate was obtained by addition of $1 \mathrm{ml}$ of $5 \%$ TCA and centrifugation for $20 \mathrm{~min}$ at $4^{\circ} \mathrm{C}$. The pellets were resuspended in $70 \mu \mathrm{l}$ of $1 \times$ sample buffer and neutralized with $30 \mu \mathrm{l}$ of $2 \mathrm{M}$ Tris-base. Ten to fifteen microliters were used for fractionation on SDS-PAGE and Western blot analysis.

Yeast cells were fractionated essentially as described $\mathrm{Be}$ langer et al. 1994). Briefly, yeast cells (80-100 OD ${ }_{600}$ units, $1.10^{9}$ cells) were spheroplasted and lysed in cold $20 \mathrm{~mm}$ HEPES- $\mathrm{HCl}$ (pH 7.5), $5 \mathrm{mM} \mathrm{M} \mathrm{gCl}_{2}$, and protease inhibitors, followed by vortexing and incubation on ice for $5 \mathrm{~min}$. Lysates were spun at $9000 \mathrm{rpm}$ at $4^{\circ} \mathrm{C}$ for $45 \mathrm{~min}$. The supernatant (S) was decanted, and the pellet was resuspended in $5 \mathrm{ml}$ of ice-cold $20 \mathrm{~mm}$ HEPES- $\mathrm{HCl}(\mathrm{pH} 7.4), 5 \mathrm{~mm} \mathrm{M} \mathrm{MCl}_{2}, 1 \mathrm{M} \mathrm{NaCl}$, and protease inhibitors, incubated on ice for $10 \mathrm{~min}$, and centrifuged at 9000 rpm for $45 \mathrm{~min}$. The supernatant $(\mathrm{P})$ was collected. Total lysate $(T), S$, and $P$ fractions were precipitated with TCA before fractionation on SDS-PAGE and Western blot analysis.

\section{Western blot analysis}

TCA precipitates in $1 \times$ sample buffer were boiled and fractionated on $10 \%$ SDS-polyacrylamide gels. The gels were transferred to nitrocellulose filters by electroblotting according to standard methods (Ausubel et al. 1994). The filters were incubated overnight with a rabbit polyclonal antibody directed against the Riplp FG repeats (1:2000 dilution) or with a mouse polyclonal antibody directed against the Riplp unique carboxyl terminus (1:2000). Immunoreactive bands were detected by ECL (Amersham Life Science, Inc.).

RIP1 synthetic lethal screen and identification of Glel alleles

Strains The original strains for the colony sectoring assay $\mathrm{CH} 1305$ and $\mathrm{CH} 1462$ (Table 3) were obtained from C. Holm (Kranz and Holm 1990; Holm 1993). The CH1305 RIP1 (FSY5) and $\mathrm{CH} 1462 \Delta$ RIP1 (FSY 6) were generated using the same strat-

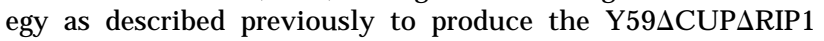
strain (FSY2) (Stutz et al. 1995).

Plasmids Two screens were performed successively with two different screening plasmids. The screening plasmid pFS478 was constructed by inserting the 1.9-kb HindlII RIP1 fragment of pFS724 into the Sall site of pCH1122 (Kranz and Holm 1990; Holm 1993) using Sall linkers. The screening plasmid pFS652 was constructed by inserting the 3.5-kb RIP1 HindllI genomic fragment of pFS398 (see above) into the Sall site of pCH1122 using Sall linkers. pFS398 was used as the testing plasmid in both screens.

Screens In the first screen, FSY 5 and FSY 6 strains transformed with pFS478 were grown in U ra ${ }^{-}$medium, plated on YPD $+4 \%$ glucose and mutagenized by UV (UV Stratalinker 1800, Stratagene) to produce $40 \%-50 \%$ cell death. A total of 200,000 colonies were screened for a nonsectoring (Sect ${ }^{-}$) phenotype. N onsectoring colonies were subscreened as described (Holm 1993). A single nonsectoring mutant strain (FSY 15) was sel ected. Backcross of this mutant with the starting wild-type strain (FSY5) indicated the presence of a single recessive mutation. To clone the mutant gene, the FSY 15 strain was transformed with a p366based (LEU2/CEN) yeast genomic library (Liao et al. 1993); transformants were grown on $\mathrm{Leu}^{-}$plates and subsequently replica-plated to 5-fluoro-orotic acid (5-FOA) plates. Plasmid DNA was recovered from strains that became 5-FOA resistant and retransformed into FSY 15. The genomic sequences that rescued the Sect ${ }^{-}$phenotype in FSY 15 were partial ly sequenced and subcloned. A 5.5-kb Sphl fragment containing the GLEl gene rescued the Sect ${ }^{-}$phenotype of FSY 15.

In the second screen, FSY 5 and FSY 6 strains transformed with pFS652 were grown in U ra- medium to $5.10^{7}$ cells $/ \mathrm{ml}$, mutagenized with ethylmethylsulfonate (EMS) as described (Lawrence 1991) to produce $40 \%-50 \%$ cell death, and plated on YPD $+4 \%$ glucose plates. N onsectoring colonies were identified and subscreened as described above. Mating with FSY 15 (glel-1) and complementation analysis identified the mutant strains FSY 20 and FSY 23 as containing the glel-2 and glel-3 alleles, respectively. The mutations in the Glel alleles were identified by PCR amplification of genomic DNA prepared from 
FSY 15, FSY20, and FSY 23 and by PCR sequencing of both strands; this procedure was repeated twice.

Plasmid shuffling The growth of the Glel mutant strains in the presence of different Riplp-expressing plasmids was examined by transformation of the synthetic lethal strains with vector p366, or various RIP1 constructs. Transformants were se lected on $\mathrm{Leu}^{-}$plates and subsequently streaked on 5-FOA plates to select for strains that had lost the URA3 ADE3 CEN screening plasmids (pFS478 or pFS652). The growth of the 5FOA resistant strains was analyzed on plates at $25^{\circ} \mathrm{C}$ and $37^{\circ} \mathrm{C}$.

\section{Acknowledgments}

We thank $C$. Cole and colleagues for communicating data before publication. We are grateful to P. Silver, L. Davis, and I. M attaj for critical reading of the manuscript. Our thanks also go to $L$. Liu for antibody preparation, E. Dougherty for hel $p$ with figures, and L.A. Monaghan for secretarial assistance.

The publication costs of this article were defrayed in part by payment of page charges. This article must therefore be hereby marked "advertisement" in accordance with 18 USC section 1734 solely to indicate this fact.

\section{References}

Ausubel, F.M., R. Brent, R.E. Kingston, D.D. Moore, J.G. Seidman, J.A. Smith, and K. Struhl. 1994. Short protocols in molecular biology, 2nd ed. Greene Publishing Associates, New York, NY.

Belanger, K.D., M.A. Kenna, S. Wei, and L.J. Davis. 1994. Genetic and physical interactions between Srplp and nuclear pore complex proteins Nup1p and Nup2p. J. Cell Biol. 126: 619-630.

Bender, A. and J.R. Pringle. 1991. Use of a screen for synthetic lethal and multicopy suppressee mutants to identify two new genes involved in morphogenesis in Saccharomyces cerevisiae. Mol. Cell. Biol. 11: 1295-1305.

Bogerd, H.P., R.A. Fridell, S. Madore, and B.R. Cullen. 1995. Identification of a novel cellular cofactor for the Rev/Rex class of retroviral regulatory proteins. Cell 82: 485-494.

Bogerd, H.P., R.A. Fridell, R.E. Benson, J. Hua, and B.R. Cullen. 1996. Protein sequence requirements for function of the human T-cell leukemia virus type 1 Rex nuclear export signal delineated by a novel in vivo randomization-selection assay. Mol. Cell. Biol. 16: 4207-4214.

Corbett, A.H. and P.A. Silver. 1997. Nucleocytoplasmic transport of macromolecules. Microbiol. Mol. Biol. Rev. 61: 193211.

Cullen, B.R. and M.H. Malim. 1991. The HIV-1 rev protein: Prototype of a novel class of eukaryotic post-transcriptional regulators. Trends Biol. Sci 16: 346-350.

Davis, L.I. 1995. The nuclear pore complex. Annu. Rev. Biochem. 64: 865-896.

Del Priore, V., C.A. Snay, A. Bahr, and C.N. Cole. 1996. The product of the Saccharomyces cerevisiae RSS1 gene, identified as a high-copy suppressor of the rat7-1 temperaturesensitive allele of the RAT7/NUP159 nucleoporin, is re quired for efficient mRNA export. Mol. Biol. Cell 7: 16011621.

Doye, V. and E.C. Hurt. 1995. Genetic approaches to nuclear pore structure and function. Trends Genet. 11: 235-241.

Fischer, U., J. Huber, W.C. Boelens, I.W. Mattaj, and R. Luhrmann. 1995. The HIV-1 Rev activation domain is a nuclear export signal that accesses an export pathway used by specific cellular RNAs. Cell 82: 475-483.
Fridell, R.A., U. Fischer, R. Luhrmann, B.E. Meyer, J.L. M einkoth, M.H. Malim, and B.R. Cullen. 1996. Amphibian transcription factor IIIA proteins contain a sequence element functionally equival ent to the nuclear export signal of human immunodeficiency virus type 1 Rev. Proc. Natl. Acad. Sci 93: 2936-2940.

Fritz, C.C. and M.R. Green. 1996. HIV Rev uses a conserved cellular protein export pathway for the nucleocytoplasmic transport of RN As. Curr. Biol. 6: 848-854.

Fritz, C.C., M.L. Zapp, and M .R. Green. 1995. A human nucleoporin-like protein that specifically interacts with HIV Rev. Nature 376: 530-533.

Gerace, L. 1995. N uclear export signals and the fast track to the cytoplasm. Cell 82: 341-344.

Goldstein, A.L., C.A. Snay, C.V. Heath, and C.N. Cole. 1996. Pleiotropic nuclear defects associated with a conditional allele of the novel nucleoporin Rat9p/N up85p. Mol. Biol. Cell 7: 917-934.

Gorlich, D. and I.W. Mattaj. 1996. Nucleocytoplasmic transport. Science 271: 1513-1518.

Grandi, P., S. Emig, C. Weise, F. Hucho, T. Pohl, and E.C. Hurt. 1995. A novel nuclear pore protein Nup82p which specifically binds to a fraction of N splp. J. Cell Biol. 130: 12631273.

Guddat, U., A.H. Bakken, and T. Pieler. 1990. Protein-mediated nuclear export of RNA: 5 S rRN A containing small RN Ps in Xenopus oocytes. Cell 60: 619-628.

Guthrie, C. and G.R. Fink. 1991. Guide to yeast genetics and molecular biology. Methods Enzymol. 194: 389-398.

Holm, C. 1993. A functional approach to identifying yeast homologs of genes from other species. Methods 5: 102-109.

Hurwitz, M.E. and G. Blobel. 1995. N UP82 is an essential yeast nucleoporin required for poly $(A)^{+}$RN A export. J. Cell Biol. 130: 1275-1281.

lovine, M.K. and S.R. Wente. 1997. A nuclear export signal in Kap95p is required for both recycling the import factor and interaction with the nucleoporin GLFG repeat regions of N up116p and N up100p. J. Cell Biol. 137: 797-811.

Izaurralde, E., J. Lewis, C. Gamberi, A. Jarmolowski, C. M cGuigan, and I.W. Mattaj. 1995. A cap-binding protein complex mediating U snRN A export. Nature 376: 709-712.

Izaurral de, E., A. Jarmolowski, C. Beisel, I.W. Mattaj, G. Dreyfuss, and U. Fischer. 1997. A role for the M 9 transport signal of hnRNP A 1 in mRN A nuclear export. J. Cell Biol. 137: 2735.

Jarmolowski, A., W.C. Boelens, E. Izaurralde, and I.W. Mattaj. 1994. N uclear export of different classes of RN A is mediated by specific factors. J. Cell Biol. 124:(5) 627-635.

Koepp, D.M. and P.A. Silver. 1996. A GTPase controlling nuclear trafficking: Running the right way or walking randomly. Cell 87: 1-4.

Kranz, J.E. and C. Holm. 1990. Cloning by function: An alternative approach for identifying yeast homologs of genes from other organisms. Proc. Natl. Acad. Sci 87: 6629-6633.

Lawrence, C.W. 1991. Classical mutagenesis techniques. In Methods in enzymology (ed. C. Guthrie and G.R. Fink), pp. 273-281. Academic Press, San Diego, CA.

Lee, M.S., M. Henry, and P.A. Silver. 1996. A protein that shuttles between the nucleus and the cytoplasm is an important mediator of RNA export. Genes \& Dev. 10: 12331246.

Legrain, P. and M. Rosbash. 1989. Some cis- and trans-acting mutants for splicing target pre-mRN A to the cytoplasm. Cell 57: 573-583.

Liao, X.C., J. Tang, and M. Rosbash. 1993. An enhancer screen identifies a gene that encodes the yeast $U 1$ snRN $P$ A protein: 
Implications for snRN P protein function in pre-mRN A splicing. Genes \& Dev. 7: 419-428.

Lindquist, S. 1986. The heat-shock response. Annu. Rev. Biochem. 55: 1151-1191.

Lindquist, S. and E.A. Craig. 1988. The heat-shock proteins. Annu. Rev. Genet. 22: 631-677.

Maniatis, T., E.F. Fritsch, and J. Sambrook. 1982. Molecular cloning. A laboratory manual. Cold Spring Harbor Laboratory, Cold Spring Harbor, NY.

Melchior, F. and L. Gerace. 1995. Mechanisms of nuclear protein import. Curr. Opin. Cell Biol. 7: 310-318.

Michael, M.W., M. Choi, and G. Dreyfuss. 1996. A nuclear export signal in hnRNP A1: A signal-mediated, temperaturedependent nuclear protein export pathway. Cell 83: 415-422.

Murphy, R. and S.R. Wente. 1996. An RNA-export mediator with an essential nuclear export signal. Nature 383: 357360.

N eville, M., F. Stutz, L. Lee, L.I. Davis, and M. Rosbash. 1997. Evidence that the importin-beta family member Crmlp bridges the interaction between Rev and the nuclear pore complex during nuclear export in S. cerevisiae. Curr. Biol. 7: 767-775

Nigg, E.A. 1997. N ucleocytoplasmic transport: Signals, mechanisms and regulation. Nature 386: 779-787.

N onet, M., C. Scafe, J. Sexton, and R. Young. 1987. Eucaryotic RNA polymerase conditional mutant that rapidly ceases mRN A synthesis. Mol. Cell. Biol. 7: 1602-1611.

Pante, N. and U. Aebi. 1995. Exploring nuclear pore complex structure and function in molecular detail. J. Cell Sci (Suppl.) 19: 1-11.

- - . 1996. Toward the molecular dissection of protein import into nuclei. Curr. Opin. Cell Biol. 8: 397-406.

Pikielny, C.W. and M. Rosbash. 1985. mRN A splicing efficiency in yeast and the contribution of nonconserved sequences. Cell 41: 119-126.

Rout, M.P. and S.R. Wente. 1994. Pores for thought: Nuclear pore complex proteins. Trends Cell Biol. 4: 357-365.

Saavedra, C., K.-S. Tung, D.C. Amberg, A.K. Hopper, and C.N . Cole. 1996. Regulation of mRN A export in response to stress in Saccharomyces cerevisiae. Genes \& Dev. 10: 1608-1620.

Saavedra, C.A., C.M. Hammell, C.V. Heath, and C.N. Cole. 1997. Export of heat shock mRN As following stress in Saccharomyces cerevisiae employs a distinct pathway defined by Riplp and also requires a subset of factors essential for export of poly(A) ${ }^{+}$mRNA. Genes \& Dev. (this issue).

Segref, A., K. Sharma, V. Doye, A. Hellwig, J. Huber, R. Luhrmann, and E. Hurt. 1997. M ex67p, a novel factor for nuclear mRNA export, binds to both poly $(\mathrm{A})^{+} \mathrm{RNA}$ and nuclear pores. EMBO J. 16: 3256-3271.

Sini ossoglou, S., C. Wimmer, M. Rieger, V. Doye, H. Tekotte, C. Weise, S. Emig, A. Segref, and E.C. Hurt. 1996. A novel complex of nucleoporins, which includes Sec13p and a Sec13p homolog, is essential for normal nuclear pores. Cell 84: 265275.

Sodroski, J., W.C. Goh, C. Rosen, A. Dayton, E. Terwilliger, and W. Haseltine. 1986. A second post-transcriptional trans-activator gene required for HTLV-III replication. Nature 321: 412-417.

Stutz, F. and M. Rosbash. 1994. A functional interaction between Rev and yeast pre-mRNA is related to splicing complex formation. EMBO J. 13: 4096-4104.

Stutz, F., M. N eville, and M. Rosbash. 1995. Identification of a novel nuclear pore-associated protein as a functional target of the HIV-1 Rev protein in yeast. Cell 82: 495-506.

Stutz, F., E. Izaurral de, I.W. Mattaj, and M. Rosbash. 1996. A role for nucleoporin FG repeat domains in export of human immunodeficiency virus type 1 Rev protein and RN A from the nucleus. Mol. Cell. Biol. 16: 7144-7150.

Stutz, F., J. Tang, and M. Rosbash. 1997. Synthetic lethal/enhancer screening to identify snRN A-protein and protein-protein interactions in yeast pre-mRN A splicing. The practical approach series (ed. C. Smith) Oxford University Press, Oxford, UK. (in press).

Visa, N ., A.T. Alzhanova-Ericsson, X. Sun, E. Kiseleva, B. Bjorkroth, T. Wurtz, and B. Daneholt. 1996a. A pre-mRN A-binding protein accompanies the RN A from the gene through the nuclear pores and into polysomes. Cell 84: 253-264.

Visa, N., E. Izaurral de, J. Ferreira, B. Daneholt, and I.W. M attaj. 1996b. A nuclear cap-binding complex binds balbiani ring pre-mRN A cotranscriptionally and accompanies the ribonucleoprotein particle during nuclear export. J. Cell Biol. 133: 5-14.

Wach, A., A. Brachat, R. Pohlmann, and P. Philippsen. 1994. $\mathrm{N}$ ew heterologous modules for classical or PCR-based gene disruptions in Saccharomyces cerevisiae. Yeast 10: 17931808.

Wen, W., J.L. M einkoth, R.Y. Tsien, and S.S. Taylor. 1995. Identification of a signal for rapid export of proteins from the nucleus. Cell 82: 463-473. 


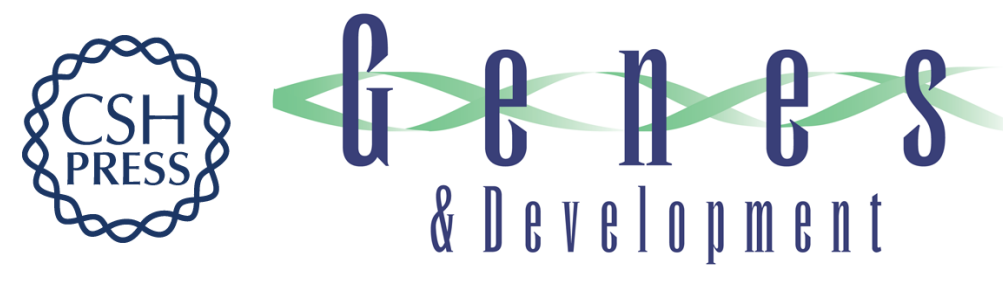

\section{The yeast nucleoporin Rip1p contributes to multiple export pathways with no essential role for its FG-repeat region}

Françoise Stutz, Julia Kantor, Dong Zhang, et al.

Genes Dev. 1997, 11:

Access the most recent version at doi:10.1101/gad.11.21.2857

References

This article cites 48 articles, 20 of which can be accessed free at: http://genesdev.cshlp.org/content/11/21/2857.full.html\#ref-list-1

\section{License}

Email Alerting

Receive free email alerts when new articles cite this article - sign up in the box at the top Service right corner of the article or click here.

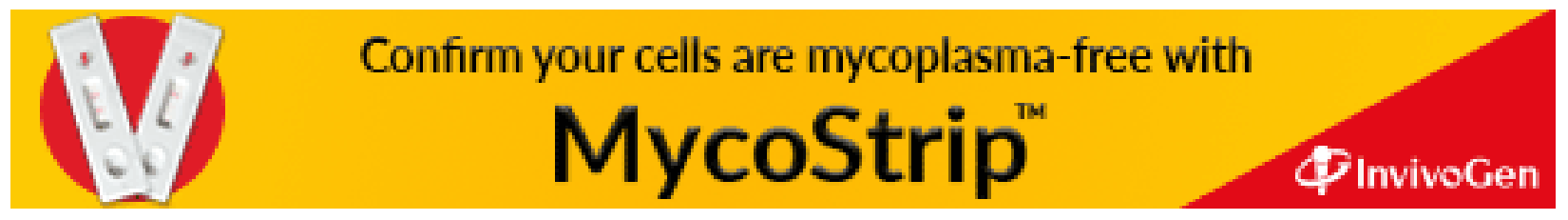

